\title{
Educational mismatches and skills: New empirical tests of old hypotheses
}

Citation for published version (APA):

Levels, M., van der Velden, R. K. W., \& Allen, J. P. (2013). Educational mismatches and skills: New empirical tests of old hypotheses. Maastricht University, Graduate School of Business and Economics. GSBE Research Memoranda No. 062 https://doi.org/10.26481/umagsb.2013062

Document status and date:

Published: 01/01/2013

DOI:

10.26481/umagsb.2013062

Document Version:

Publisher's PDF, also known as Version of record

\section{Please check the document version of this publication:}

- A submitted manuscript is the version of the article upon submission and before peer-review. There can be important differences between the submitted version and the official published version of record. People interested in the research are advised to contact the author for the final version of the publication, or visit the DOI to the publisher's website.

- The final author version and the galley proof are versions of the publication after peer review.

- The final published version features the final layout of the paper including the volume, issue and page numbers.

Link to publication

\footnotetext{
General rights rights.

- You may freely distribute the URL identifying the publication in the public portal. please follow below link for the End User Agreement:

www.umlib.nl/taverne-license

Take down policy

If you believe that this document breaches copyright please contact us at:

repository@maastrichtuniversity.nl

providing details and we will investigate your claim.
}

Copyright and moral rights for the publications made accessible in the public portal are retained by the authors and/or other copyright owners and it is a condition of accessing publications that users recognise and abide by the legal requirements associated with these

- Users may download and print one copy of any publication from the public portal for the purpose of private study or research.

- You may not further distribute the material or use it for any profit-making activity or commercial gain

If the publication is distributed under the terms of Article $25 \mathrm{fa}$ of the Dutch Copyright Act, indicated by the "Taverne" license above, 
Mark Levels, Rolf van der Velden, Jim Allen

Educational mismatches and skills: New empirical tests of old hypotheses

RM/13/062

\section{GSBE}

Maastricht University School of Business and Economics

Graduate School of Business and Economics

P.O Box 616

NL- 6200 MD Maastricht

The Netherlands 


\title{
Educational mismatches and skills: new empirical tests of old hypotheses $^{1}$
}

Mark Levels, Rolf van der Velden and Jim Allen

\begin{abstract}
In this paper, we empirically explore how the often reported relationship between overeducation and wages can best be understood. Exploiting the newly published Programme for International Assessment of Adult Competencies (PIAAC) data (OECD 2013), we are able to achieve a better estimation of the classical ORU-model (Duncan and Hoffman, 1981), by controlling for heterogeneity of observable skills. Our findings suggest that 1) a considerable part of the effect of educational mismatches can be attributed to skills heterogeneity, and 2) that the extent to which skills explain educational mismatches varies by institutional contexts. These observations suggest that skills matter for explaining wage effects of education and educational mismatches, but the extent to which this is the case also depends on institutional contexts.
\end{abstract}

JEL classification: I21, I25, J23, J24

Keywords: Overeducation, skills, heterogeneous skills theory, labour market institutions

\footnotetext{
${ }^{1}$ The authors wish to thank Lex Borghans and Didier Fouarge for their helpful comments on an earlier version of this paper.
} 


\section{Introduction}

In this paper, we empirically explore how the often reported relationship between overeducation and wages can best be understood. Exploiting the newly published data from the Programme for International Assessment of Adult Competencies PIAAC (OECD 2013), we are able to achieve a better estimation of the classical ORU-model (Duncan and Hoffman, 1981), by controlling for heterogeneity of observable skills. Our findings suggest that a considerable part of the effect of educational mismatches can be attributed to skills heterogeneity. Our observations further suggest that the extent to which skills explain wage effects of education and educational mismatches also depends on institutional contexts.

The incidence and wage effects of overeducation have been well-established by empirical studies ( $c f$. Green, McIntosh and Vignoles, 1999; Groot and Maassen van den Brink, 2000; Hartog, 2000; Sloane, 2003; Quintini, 2011). Empirical analyses consistently show that (1) people who work in jobs for which they are overqualified earn less than workers who have the same level of education, but who work in jobs that require that level of education, and that (2) overeducated people earn more than people who work in equivalent jobs but have attained the level of schooling required for that job (Sicherman, 1991; Hersch, 1991; Garcia-Serrano and Malo-Ocana, 1996; Dekker, de Grip and Heijke, 2002; Sloane, 2003). Many papers have aimed to explain these stylized facts (Duncan and Hoffman, 1981; Hartog and Oosterbeek, 1988; Sloane et al. 1999; and McGuinness, 2006). Much of the debate has focussed on the question of whether the match between a worker's education and that required for his/her job has a distinct effect on productivity, in addition to the effect of education itself. Many authors have proposed theoretical reasons for believing that this may be the case, for example citing job assignment theory (Hartog, 1977; Sattinger, 1993; 2012). This theory proposes that, even if we accept that the skills obtained in education contribute positively to productivity in general, the extent to which workers can use those skills may 
depend to some extent on productivity limits imposed by job characteristics. For overeducated workers, job constraints may allow only a limited use of their skills, which in turn limits their productivity and consequently their wages. This would suggest that overeducated workers underutilise their skills and vice versa undereducated workers overutilise their skills.

However, research shows that educational mismatches and skill mismatches correlate only weakly (Allen and Van der Velden, 2001; Green and McIntosh, 2007; Quintini, 2011). Two explanations have been forward to explain the observed effects of educational mismatches and the weak relation with skills mismatches.

Heterogeneous skills theory (Allen and Van der Velden, 2001; Green and McIntosh, 2007) points out that considerable variation in skills exists within educational levels. If we accept that this is the case, it is likely that relatively high-skilled workers will tend to be sorted into more complex jobs that match their skills better than jobs that formally require their own level of education, while low-skilled workers will be sorted into less complex jobs that also provide a better match to their actual skill levels. According to this view, what has been labelled undereducation and overeducation may - in some cases at least - be only an adjustment by the market that shifts workers to jobs that in fact better match their capabilities than would jobs that formally require their own level of education. According to this view, it is the skills possessed by these workers, rather than the mismatch they nominally experience, that is driving the observed wage effects.

Allen and Van der Velden (2001) propose an alternative explanation for the wage effects of over- and undereducation and their weak relation to skills mismatches, namely that it is the result of institutional regulation of the labour market. In most countries there are labour laws and institutions designed to protect the rights of workers in the labour market. In part at least, these laws and institutions have arisen in response to uncertainty as to what constitutes fair treatment. Because workers' skills and productivity can rarely be observed 
perfectly, pay rates will need to be established through some form of bargaining. It has been forcefully argued by scholars such as Spence (1973) that under such conditions employers aim to base a given worker's wages on perceived signals of the likely productivity of workers with given observable characteristics (such as specific educational qualifications) working in a comparable job, or performing comparable tasks. It is usually supposed that resorting to such signals will be a temporary measure that will quite quickly become unnecessary as information about the actual performance of the worker becomes available, but when labour laws and institutions become powerful it may be difficult to achieve this. When wage setting is strongly institutionalized, basing wages on proxies or signals such as the required education for a given job or the educational qualifications of the worker may become a permanent feature of wage setting processes rather than a temporary stopgap solution in lieu of better information. Similarly, labour laws in a country may restrict employers' ability to adjust wages to match performance, or to dismiss underperforming workers. If this is true, there may be substantial wage effects of educational mismatches that cannot be explained by individual productivity differences, whether due to differences in skills or to poor matching between actual and required skills. If so, we would expect to observe these 'unexplained' wage effects of educational mismatches to occur much more in situations where wages are more affected by institutional arrangements.

To date, the debate about which theory best explains the relationship between overeducation and wages has been hampered by data problems (Sloane, 2003). The most important problem is that there has been no large scale dataset that combines measures of both required education and skills. Quintini (2011) has attempted to use the International Adult Literacy Survey (IALS) for this purpose, but although this dataset includes good measures of skills, it lacks reliable data on required level of education. Other datasets simply lack good 
measures of skills, or are not large enough to cover institutional variation across different countries.

The recently conducted international large-scale assessment PIAAC provides reliable measurements of all the elements we need, i.e. wage, years of acquired and required schooling, as well as direct measures of key information processing skills. As such, these data allow us to better distinguish between the various theoretical explanations for the relationship between educational (mis)matches and wages than any previous data set. Although the measured skills are not the perfect measure of all relevant abilities, and much skills heterogeneity will plausibly remain unobserved, these data can be used to establish whether the relationships between wages and overeducation, undereducation and required education can partly be attributed to skills heterogeneity. Furthermore, the cross-national character of the data allows for exploring the role of labour market institutions.

In the next section, we formally deduce hypotheses from the abovementioned theories. More specifically, we seek to answer the following research questions:

1) To what extent are required education, overeducation and undereducation related to individual wages?

2) To what extent can the effects of required education, overeducation, and undereducation on individual wages be explained by individual differences in skills?

3) To what extent is there cross-national variation in the extent to which the relationship between wages on the one hand, and required education, overeducation, and undereducation on the other hand can be explained by skills heterogeneity?

4) To what extent is this cross-national variation related to differences in labour market institutions? 


\section{Theory and hypotheses}

In a significant expansion of the classic Mincerian wage function (Mincer, 1974), Duncan and Hoffman (1981) proposed a model that allows for distinguishing between individuals' attained level of education and the level of education required in their job. In this so-called ORU-model, it is possible to estimate the effects of overeducation $O$, required education $R$ and undereducation $U$ on wages. The ORU model stipulates a relationship between wages on the one hand, and overeducation, required education and undereducation, on the other hand. In a cross-national setting, the model specifications are of the general form:

$\ln W_{i}=\delta_{o} E_{i}^{o}+\delta_{r} E_{i}^{r}+\delta_{u} E_{i}^{u}+\boldsymbol{c}_{i}^{\prime} \alpha+\boldsymbol{x}_{i}{ }_{i} \beta+\varepsilon_{i}$

in which $W i$ is the observed wage of individual $i, E^{o}{ }_{i}$ is the number of years of overeducation, $E_{i}^{r}$ is the number of years of required education, and $E^{u}{ }_{i}$ the number of years of undereducation. To account for unobserved heterogeneity between countries, we include a vector with country fixed effects dummies, denoted as $\boldsymbol{c}$. Furthermore, $\boldsymbol{x}$ is a vector that contains control variables, such as age and work experience, and $\varepsilon_{i}$ is an idiosyncratic error term.

Now, we allow for differentiation between education and skills. We expand Equation [1] with a vector of direct observations of skills, denoted as $\boldsymbol{s}$. Now, the model reads:

$\ln W_{i}=\delta_{o} E_{i}^{o}+\delta_{r} E_{i}^{r}+\delta_{u} E_{i}^{u}+\boldsymbol{c}^{\prime}{ }_{i} \alpha+\boldsymbol{x}_{\boldsymbol{i}} \boldsymbol{\beta} \beta+\boldsymbol{s}^{\prime} \gamma+\varepsilon_{i}$

In Equation [2], the wage returns of skills are denoted by $\gamma$. Note that we do not assume that an individual's education and skills are uncorrelated. On the contrary, we expect that education, but also control variables like age and work experience affect skills, but that 
conditional on these variables, skills can be quite heterogeneous. By including the skills in the ORU model, we will be able to see whether skills affect wages over and above their effect through education.

As described earlier, previous findings show that:

$\delta_{r}>\delta_{o}>\left|\delta_{u}\right|>0$

The basic idea of this paper is that the various theories that have been put forward make different predictions about the extent to which these parameters are driven by individual skills differences, and about their cross-national variability. In the remainder of this section, we will formally derive such hypotheses. In order to do so, we will specify two (nested) specifications of Equation [2], one in which skills are not controlled for, and a second specification in which skills are controlled for. For reasons of clarity and precision, we describe the various hypotheses in logical terms, and will treat the two specifications as two different conditions under which the same model will yield different predictions. Under the first specification, all skills variables are restricted to zero, so that $\boldsymbol{s}=\mathbf{0}$. Note that under this specification, Equation [2] collapses to the standard ORU model described in Equation [1]. Under the second specification, we put no restrictions on the skills variables in Equation [2], so that $\mathbf{s} \neq \mathbf{0}$.

Based on these specifications, we can formulate the following formal hypotheses based on the heterogeneous skills theory. In its strongest form, the heterogeneous skills theory leads to the following prediction:

Hypothesis 1 (strong):

$\delta_{r}=\delta_{o}=\left|\delta_{u}\right|=0 \quad \&$

$\gamma>0$ 
In words: after controlling for skills, we expect no significant effect of required education, overeducation or undereducation on wages, while we do expect skills to have an effect. Note that testing this hypothesis would require that we observe all relevant skills, which is highly improbable, if not impossible. Under these conditions, a weaker version of this hypothesis is more realistic. Such hypothesis states that a significant part of these effects is explained by observed skills. In that case the absolute values of $\delta_{r}, \delta_{o}$ and $\delta_{u}$ are significantly lower in Equation [2] than in Equation [1].

Hypothesis 1 (weak):

$\left(\delta_{r} \mid \mathbf{s}>0\right)<\left(\delta_{r} \mid \mathbf{s}=0\right) \quad \&$

$\left(\delta_{o} \mid \mathbf{s}>0\right)<\left(\delta_{o} \mid \gamma=0\right) \quad \&$

$\left(\left|\delta_{u}\right| \mid \mathbf{s}>0\right)<\left(\left|\delta_{u}\right| \mid \mathbf{s}=0\right) \quad \&$

$\gamma>0$

To answer research questions 3 and 4, we will consider Equations [1] and [2] separately for each country. The country estimates of $\gamma$ in Equation [2] will provide us with an estimate of the extent to which skills affect wages in the different countries and comparing $\delta_{r}, \delta_{o}$ and $\delta_{u}$ in Equations [1] and [2] can indicate the extent to which skills explain the wage returns to overeducation, undereducation and required education in each country. So, let $\zeta_{r}^{c}$ be the proportion of the wage returns to required education explained by skills in country $c, \zeta_{o}^{c}$ be the proportion of the wage returns to overeducation explained by skills in country $c$, and $\zeta_{u}{ }^{c}$ be the proportion of the wage returns to undereducation explained by skills in country $c$. Furthermore, $\delta_{r}^{c}$ is the effect of required education on wages in country $c, \delta_{o}^{c}$ is the effect of 
overeducation on wages in country $c, \delta_{u}{ }^{c}$ is the effect of undereducation on wages in country. Then, it follows that:

$$
\begin{aligned}
& \zeta_{r}^{c}=\left(\left(\delta_{r}^{c} \mid \mathbf{s}=0\right)-\left(\delta_{r}^{c} \mid \mathbf{s}>0\right)\right) /\left(\delta_{r}^{c} \mid \mathbf{s}=0\right) \\
& \zeta_{o}^{c}=\left(\left(\delta_{o}^{c} \mid \mathbf{s}=0\right)-\left(\delta_{o}^{c} \mid \mathbf{s}>0\right)\right) /\left(\delta_{o}^{c} \mid \mathbf{s}=0\right) \\
& \zeta_{u}^{c}=\left(\left(\left|\delta_{u}{ }^{c}\right| \mid \mathbf{s}=0\right)-\left(\left|\delta_{u}{ }^{c}\right| \mid \mathbf{s}>0\right)\right) /\left(\left|\delta_{u}{ }^{c}\right| \mid \mathbf{s}=0\right)
\end{aligned}
$$

To answer research question 4 we can then estimate the following equations

$$
\begin{aligned}
& \gamma_{c}=\lambda_{0}+\lambda_{s} L M P I_{c}+\varepsilon_{c} \\
& \zeta_{r}^{c}=\lambda_{0}+\lambda_{r} L M P I_{c}+\varepsilon_{c} \\
& \zeta_{o}^{c}=\lambda_{0}+\lambda_{0} L M P I_{c}+\varepsilon_{c} \\
& \zeta_{u}^{c}=\lambda_{0}+\lambda_{u} L M P I_{c}+\varepsilon_{c}
\end{aligned}
$$

in which $L M P I_{c}$ is the index of labour market protection legislation in country $c$ and $\varepsilon_{c}$ is an idiosyncratic error term. The parameter $\lambda_{0}$ is an intercept, $\lambda_{s}$ is the relationship between labour market protectionism and the wage returns to skills by country, denoted by $\gamma_{c}$. Parameters $\lambda_{r}$, $\lambda_{o}$ and $\lambda_{u}$ denote the relationship between labour market protectionism and the extent to which wage returns to required education, overeducation and undereducation are explained by skills. Following the previous discussion on institutional theory, we can predict that:

Hypothesis 2:

$\begin{array}{ll}\text { (2a) } \lambda_{s}<0 & \& \\ \text { (2b) } \lambda_{o}<0 & \& \\ \text { (2c) } \lambda_{r}<0 & \& \\ \text { (2d) } \lambda_{u}<0 & \end{array}$


In words: we expect the country-specific effects of skills on wages to be negatively related to the country's LMPI: in countries with stronger labour market institutions, skills have less effects on wages (hypothesis 2a). Moreover we expect that the country-specific proportion of the effects of required education, overeducation and undereducation that is explained by skills to be negatively related to the country's LMPI (hypotheses 2b-d). In countries with stronger labour market institutions, education related wage differentials are less related to skills.

\section{Data and measurements}

The data we use for the analyses come from the PIAAC survey, collected by the OECD (2013a) in 24 highly industrialized countries. The survey is designed to provide valid and reliable estimates of adults' competences in key information-processing skills, to identify proficiency differences between sub-groups of the population, to understand development, maintenance and use of skills, as well as to determine the impact of proficiency levels on life chances (OECD, 2013b). National samples contain over 5000 adults between the age of 16 and 65. Respondents were interviewed using computer assisted personal interviews, although for the testing pencil-and-paper data collection strategies were also used. Respondents were given assessment tests designed to directly measure their cognitive skills on various domains. More specifically, these tests measured numerical and literacy skills, as well as respondents' capacity to solve problems in technology-rich environments. The data also hold information on respondents' non-cognitive skills, on key demographic and socio-economic background characteristics, as well as on skills use in the work place and at home. The survey is crossculturally and cross-nationally valid.

To prepare the data for our analyses, we have made a number of selections. Details are to be found in the Appendix. First, we only selected males who were employed fulltime. This was based on the reported number of usual working hours per week. Fulltime workers are 
defined as workers with a minimum of 36 working hours per week. To avoid outliers, we excluded everybody reporting more than 80 working hours per week. We excluded those who were self-employed, people who served in the armed forces, as well as unpaid family workers. To avoid outliers in the wage distribution we excluded the top and bottom one percent in each country. We excluded France and Russia, as these data were not yet available as well as Australia. The working sample consists of some 1200 cases in most countries. In Canada the sample existed of some 6069 cases, from which we took a random sample of $20 \%$, resulting in $N_{\text {Canada }}=1190$ cases to reduce possible bias due to oversampling of Canadian respondents. Missing values were deleted listwise. The total working sample contains $\mathrm{N}=26322$ respondents from 21 countries.

\section{[Table 1 here]}

\section{Measurements}

Below, we will discuss the measurement of the variables we use in detail. An overview of descriptive statistics of all the variables in our model is given in Table 1.

Wages: as our dependent variable, we use the natural logarithm of the monthly wage, adjusted for purchasing power parity to account for cross-national differences. Respondents in the top and bottom $1 \%$ on this variable in each country are omitted from the analyses to avoid outliers. Monthly wages in our data set range from USD 513 to USD 213198. The mean wage is USD 3490.

Educational attainment is measured in PIAAC in the nominal number of years respondents spent in formal education. The measure is derived from the reported highest level of education in national education systems, converted into nominal years of schooling by the PIAAC consortium and country experts (OECD, 2013b). 
Required education: the PIAAC questionnaire contains a question asking respondents what education level they thought was required for their current jobs. Verbatim, this question was: "If applying today, what would be the usual qualifications, if any, that someone would need to GET this type of job?". Based on the answers respondents gave to this question and information about national education systems, this was converted into cross-nationally comparable measure of nominal years of formal education needed to get the job (OECD, 2013b). The measure ranges from 0 to 22 years, with a mean of 12.9 years.

Overeducation: our measure is derived from the measures of respondents' educational attainment and the education level required for their job. We use the operational definition of overeducation common in this line of literature, and define overeducation as the extent to which individuals have attained an educational level that is higher than is required for the job they have. More formally, let overeducation be $E^{O}$, required education in years of schooling be $E^{R}$, and respondents' educational attainment in years of schooling be $E^{A}$. Also, let $E^{O} \geq 0$. Then, we can define the extent of overeducation as:
$E^{O}=E^{A}-E^{R}$
if $\quad E^{A}>E^{R}$
and
$E^{O}=0$
if $\quad E^{A} \leq E^{R}$

Undereducation: Our measure of undereducation follows a similar reasoning. Undereducation is defined as the extent to which individuals have attained an educational level that is lower than is actually required for the job they have. More formally, let undereducation be $E^{U}$, and restrict $E^{U} \geq 0$. Then, we can define the extent of undereducation as:
$E^{U}=E^{R}-E^{A}$
if $\quad E^{R}>E^{A}$
and
$E^{U}=0$
if $\quad E^{R} \leq E^{A}$ 
Skills: PIAAC contains measures of three types of skills, i.e. literacy skills, numeracy skills, and skills related to problem solving in technology-rich environments (OECD, 2013b). All three skills measures are constructed using adaptive testing and plausible values are calculated using Item Response Theory (IRT). The tests on problem solving in technology rich environments were only presented to people who reported that they had at least some computer experience, were willing to take the computer-based assessment and had at least minimum levels of computer abilities. Including these tests would non-randomly reduce our sample size with almost $33 \%$. We therefore restrict ourselves to the measurements of numeracy and literacy to operationalise skills. As the skill proficiencies of literacy and numeracy are highly correlated $(r=0.905)$ we only use numeracy for the main analysis and literacy for the robustness check. The OECD (2013b) defines numeracy as "the ability to access, use, interpret and communicate mathematical information and ideas in order to engage in and manage the mathematical demands of a range of situations in adult life." The tests of numeracy measure how well respondents are able to use mathematical information to solve problems that might actually occur in real life. Numeracy is measured with 10 plausible values. We use the first of the reported plausible values as an indication of the numeracy skills of individuals.

Age: we control for life-cycle variation in wages by including respondents' age in years. We also include a quadratic term, to account for the non-linearity of the relationship between age and wages.

Work experience: we also control for the effects work experience has on wages, by including the total numbers of years respondents reported to have had paid work during their lifetime. Here too, we include a quadratic term. 
Working hours: Although we select people working fulltime (defined as 36 hours or more), there is still considerable variation in number of working hours. Therefore we control for the number of hours individuals work per week in their current job. As indicated above, we excluded respondents reporting to work more than 80 hours per week to avoid outliers. The mean number of hours worked is 43,89 .

Immigration status: we use dummies to distinguish first generation immigrants (both parents and respondent were foreign born), 1.5 generation immigrants (respondent and one parent foreign born, one parent born in test country), second generation immigrants (both parents foreign born, respondent born in test country), 2.5 generation immigrant (respondent and one parent born in test country, one parent foreign born), and remigrants (i.e. respondent foreign born, both parents non-foreign born). People without an observed history of migration are the reference category.

Country fixed effects: we control for unobserved heterogeneity between countries by including country dummies. Austria is the reference category.

Labour Market Protection Index (LMPI): As a measurement of the flexibility of labour markets, we use the Labour Market Protection Index, calculated by the OECD (2009) in OECD and selected non-OECD countries in 2008. This index is designed to measure crossnational differences in the extent to which workers in various countries are protected by employment protection legislation. It has a country-level mean of 2.10 , and ranges from 0.85 (USA) to Spain (3.11). A higher score means a higher level of employment protection.

[Figure 1] 


\section{Analyses and results}

Before we start with the actual analyses, Figure 1 shows the relation between educational mismatches and skills mismatches. In this figure, skills mismatches are proxied by the answers to the following two questions in the PIAAC questionnaire: "Do you feel that you have the skills to cope with more demanding duties than those you are required to perform in your current job?" and "Do you feel that you need further training in order to cope well with your present duties?". The answer "yes" to the first question is commonly taken as an indication of underutilisation of skills and the answer "yes" to the second question is commonly taken as an indication of overutilisation of skills (OECD, 2011). Note that the two questions are not mutually exclusive and respondents can and do report positive answers to both.

Figure 1 shows that a large proportion of workers report to have some underutilisation of skills: on average $84 \%$. Although the proportions slightly higher for overeducated workers and lower for undereducated workers, the relation is in fact quite weak, as has been reported before (Allen and Van der Velden, 2001; Green and McIntosh, 2007; Quintini, 2011). The same applies for the indicator of overutilization. On average some $35 \%$ report that additional training would be needed to better perform their current duties. This proportion is as expected somewhat higher for undereducated workers and lower for overeducated workers, but the differences are small.

Arguably these questions are only weak indicators of possible skill mismatches, due to their subjective nature. That is the very reason why we resorted to using objective test scores in the first place. In Table 2 we present the analyses using test scores as proxies for worker's skills.

[Table 2 here] 
In Model 1 we follow the classical Duncan and Hoffman (1981) ORU model, stipulating a relationship between overeducation, required education and undereducation and wages. The specifications estimated here are of the general form described in Equation [1]. In Model 2 we estimate an extended version of this model by including the numeracy skills. This model follows Equation [2].

The results of Model 1 are in line with previous findings. First, the relationship between required years of schooling and wages is positive. The strength of the relationship $\left(\delta_{r}=0,080\right)$ indicates that each additional year of required schooling, yields a wage premium of some $8 \%$. The effect of overeducation is less than half that size, with an estimate of $\left(\delta_{o}=0.033\right)$. Having more education than is required for the job pays off but not as much as the years of required education for that job. Each additional year of education yields a wage premium of some $3 \%$. Undereducation is negatively related to wages $\left(\delta_{u}=-0.021\right)$ The absolute effect size is as expected smaller than the effect size of overeducation. Each year of undereducation yields a wage penalty of some $2 \%$.

In Model 2, the proficiency score on numeracy skills is added to the model. Numeracy skills $(\gamma=0.144)$ are positively related to wages. If we compare the standardized effects, the effect size (standardised parameter $=0.124$ ) is around one third of the effect of required education $(($ standardised parameter $=0.361)$. Compared to Model 1 , the relationship between required education and wages is reduced with $16 \%$ to $\delta_{r}=0.067$. We can also see that the effect of overschooling is reduced with $28 \%$ to $\delta_{o}=0.024$. Differences in numeracy skills account for $38 \%$ of the effect of underschooling as observed in Model 1.

How do these findings bear on the hypotheses we formulated? The strong version of the heterogeneous skills theory predicted that, after controlling for skills, there would be no residual effect of required education, overeducation and undereducation on wages. That is 
clearly not the case. However, the results do clearly show that a significant part of all three effects can be explained by skills, suggesting that the weaker version of the heterogeneous skills theory is supported by the data. There are however three additional remarks that are highly relevant here.

Firstly, it must be noted that we do not observe all skills that are relevant in theory, and that by design, we cannot exclude the possibility that the relationship between overeducation and skills would be further reduced if we would be able to control for the now unobserved skills. In other words, our test of the heterogeneous skills theory is a highly conservative one.

Secondly, the expectation that it would be possible to explain all the wage variance that is related to required education, overeducation and undereducation presupposes that employers are perfectly informed about all the relevant skills and other productive attributes of workers. We deem this unrealistic. In practice, it is very plausible that there is at least some uncertainty, and as a consequence there will be some tendency to assign wages based on observable features of workers and jobs rather than entirely on actual productive skills. Consequently, even if we possessed the perfect knowledge that most employers lack, in the form of a precise measurement of all relevant skills, the strong version of the heterogeneous skills theory is unlikely to be fully confirmed. There will be some residual effect indicating that people are rewarded partly based on easily observable features such as education and job titles.

This leads directly on to the third point, which is that we would expect the size of this residual effect to depend to a large extent on the particular institutional arrangements that prevail in a country. In countries in which wage setting is largely a matter that is decided between employer and employee, with little regard needing to be paid to laws and institutions designed to protect workers' rights, we would expect the residual effect to be quite small and 
largely transient. However, in countries in which protectionist labour market laws and institutions play an important role, we would expect the residual effect to be far larger and more permanent. This is precisely the point of our second hypothesis, and it is to this that we now turn.

[Table 3 here]

Based on institutional theory, we posited the hypothesis that the extent to which individual skills affect wages over and above the effects of required education, overeducation and undereducation is larger in countries in which employment protection is lower. Moreover we hypothesized that the extent to which skills can explain the relationship between required education, overeducation and undereducation on the one hand and wages on the other hand is larger in countries in which employment protection is lower. To test these hypotheses, we examined cross-national variation in the effects of skills on wages and on the proportion of the wage effects of required education, overeducation and undereducation that can be attributed to skills. To establish this proportion for each country, we ran the model specified in Equation [2] separately for each country.

In the first column of Table 3, we present the wage effects of skills in each country according to Equation [2]. Table A2 in the Appendix presents the full models. There is indeed considerable cross-national variation in the effect of numeracy skills on wages, ranging from a low 0.052 in Czech Republic to a high 0.237 in the United Kingdom.

[Figure 2 here] 
Figure 2 presents the country-level relationship between labour market protection and the wage returns to numeracy skills. On the x-axis of the graph, we have ordered countries according to the extent to which employees enjoy legal labour market protection. The OECD index combines information about laws that protect workers against firing, but also about the extent to which labour unions can participate in collective bargaining processes, and is thus a very broad and general measure. On the y-axis the countries are ordered based on the effect of numeracy skills on wages. The figure shows that the wage returns to skills are indeed lower in countries with a stronger labour market protection.

Columns 2-4 of Table 3 present information about country differences in the extent to which skills explain the correlation between wages and required years of schooling, overeducation and undereducation. The table shows that again large cross-national variation exists. In the US (23\%), Germany (22\%), Estonia (24\%), the UK (21\%), Japan (21\%), and Canada (21\%), skills are important explanations for the returns to required education. In contrast, in Cyprus (4\%), Czech Republic (6\%) and Slovak Republic (5\%), skills contribute much less to the explanation of the relation between required education and wages. In the US (60\%), Japan (66\%), and Estonia (58\%), skills explain (nearly) all of the returns to overeducation, whereas in Cyprus, Slovak Republic and the Czech Republic barely any of this effect is explained by skills. In Estonia and the Slovak Republic the undereducation effect is fully explained by skills and also in Denmark (93\%), Japan (51\%) and the United Kingdom $(42 \%)$ the proportion of the wage effect of undereducation that is explained by skills is very high. On the other hand the proportion of the wage effect of undereducation that is explained by skills is very low in Finland (9\%), Cyprus (11\%), Czech Republic (14\%), Korea (14\%) and Spain $(9 \%)$.

[Figure 3 here] 
Figure 3 shows how labour market protection in countries is related to the extent to which wage effects of required education, overeducation and undereducation are explained by skills. On the $\mathrm{x}$-axis of the graph, we have ordered countries according to the extent to which employees enjoy legal labour market protection. On the y-axis the countries are ordered based on the extent to which the relationship between required education (top panel), overschooling (middle panel) and underschooling (bottom panel) can be explained by individuals' skills.

In the top panel of Figure 3 we can see that the extent to which the wage effects of required education are explained by skills is somewhat stronger in the low LMPI countries than in the strong LMPI countries. The middle panel of Figure 3 shows a somewhat stronger negative relationship between employment protection and the extent to which skills can explain the relationship between overeducation and wages, which is in line with the institutional hypothesis. It indicates that in strong LMPI countries the wage effects of overeducation are less driven by skills than in low LMPI countries. Furthermore, the overall proportions that are explained in each country are higher and the relation is somewhat stronger than is the case for required education.

The lower panel of Figure 3 shows that there is no relation between LMPI and the extent to which the wage effect of undereducation is explained by skills. Nonetheless, we note that a large part of the effect of undereducation is related to skills, and this holds for many countries. This reflects the situation that undereducation only occurs when people have the skills to master the job in question, which again supports the heterogeneous skills theory.

Figure 3 suggests two things. First, the effects of overeducation are more strongly related to skills than is the case for required schooling, for both low and high LMPI countries. Second, even in strong LMPI countries some of the wage effects of required education are explained by underlying differences in skill levels. Taking into account that this is a 
conservative estimate of the effect of skills, the real explanatory effect of skills in these countries might be much higher. This could reflect the fact that in collective bargaining one of the arguments for assigning higher wages to higher educational levels is because of the presumed higher skills levels.

\section{Conclusions and discussion}

In this paper, we have aimed to shed further light on explanations for the well-established relationship between overeducation and earnings. Using new empirical data (PIAAC, OECD, 2013), we were able to estimate the classical ORU-model while controlling for heterogeneity of observable skills. This allowed us to address four research questions.

First, we asked to what extent required education, overeducation and undereducation are related to individual wages. Our findings are in line with earlier studies that show that overeducated workers earn less than workers who have the same level of education, but work in jobs that require their level of education, and overeducated workers earn more than people who work in equivalent jobs but have attained the level of schooling required for that job.

Secondly, we asked to what extent the effects of required education, overeducation, and undereducation on individual wages can be explained by individual differences in skills. Our analyses show that skills heterogeneity contributes considerably to the explanation of educational mismatch. The effect of numeracy skills on wages explains some one-sixth of the wage effect of required education, and little under one-third of the wage effects of overeducation and undereducation. Considering that we only use one measure of one observable skill, these effects are in fact quite high. One can easily imagine that much more could be explained if we could have measured all relevant skills. At least we can conclude that part of the educational mismatches is just apparent and do not necessarily imply that worker's skills are heavily underutilised or overutilised. The incidence of undereducation and 
overeducation in these cases can be interpreted as an adjustment by the market that shifts workers to jobs that in fact better match their capabilities than would jobs formally requiring their own level of education. The significance of skills is also illustrated by the fact that even in strong LMPI countries some of the wage effects of required education are explained by underlying differences in skill levels. Again taking into account that this is a conservative estimate of the effect of skills, the real explanatory effect of skills in these countries is likely to be higher. This seems to suggest that even in a situation of collective bargaining one of the arguments for assigning higher wages to higher educational levels is because of the presumed higher skills levels.

In our third and fourth research questions, we asked to what extent there is crossnational variation in the extent to which the relationship between wages on the one hand, and required education, overeducation, and undereducation on the other hand can be explained by skills heterogeneity, and to what extent this cross-national variation is related to differences in labour market institutions? We clearly observe that in all countries, a considerable part of the wage effects of over- and undereducation is explained by heterogeneous skills. Notwithstanding this clear support for the heterogeneous skills theory, we also find some support for the institutional theory, which predicted that the extent to which skills can explain the wage effects of required education, overeducation and undereducation will depend strongly on the institutional context. In countries with weak labour market protection, we find stronger direct effects of skills on wages and in these countries a larger proportion of the observed wage effects can be accounted for by skills. By contrast, where labour market protection is strong, skills have a weaker direct effect on wages and account for relatively little of the wage effects of required education, overeducation and undereducation. It is hard to find an alternative explanation for these observed effects of labour market institutions. All countries in question are highly developed and although there may be differences in economic 
conditions, it is not immediately clear why numeracy skills affect wages strongly in countries like Canada, Japan and the United Kingdom and so low in Italy or Cyprus. It is unlikely that some omitted skill variable might be responsible for this. That would assume that for example in country $\mathrm{X}$ wages are strongly related to skill A and in country $\mathrm{Y}$ it would be strongly related to skill B, with little or no correlation between skill $\mathrm{A}$ and $\mathrm{B}$. That seems quite unlikely, and we think that it is plausible to infer from our findings that the extents to which individual skills affect wages is constrained by the institutional arrangements.

We conclude that these observations make plausible that skills do matter in explaining wage effects of education and educational mismatches, but that the extent to which this is the case also depends on institutional contexts. 


\section{References}

Allen J. and R. van der Velden. (2001), Educational Mismatches versus Skill Mismatches: Effects on Wages, Job Satisfaction, and On-the-Job Search, Oxford Economic Papers 3, 434-452.

Berg, I. (1970), Education and Jobs: the Great Training Robbery, New York: Praeger.

Dekker, R., A. de Grip and H. Heijke (2002), The Effects of Training and Overeducation on Career Mobility in a Segmented Labour Market, International Journal of Manpower, 23, 2, 106-125.

Duncan, G. and S. D. Hoffman (1981), The Incidence and Wage Effects of Overeducation, Economics of Education Review, 1, 1, 75-86.

García-Serrano, C. and M. Malo-Ocaña (1996), Educational Mismatch and Internal Labour Markets: Is there any relationship?, ISER Working Paper no. 1996-16, University of Essex.

Green, F., S. McIntosh and A. Vignoles (1999), Overeducation and Skills -Clarifying the Concepts, Centre for Economic Performance, Discussion Paper 435.

Green F. and S. McIntosh (2007), Is there a Genuine Under-utilization of Skills amongst the Overqualified?, Applied Economics, 39, 4, 427-439.

Groot, W. and H. Maassen van den Brink (2000), Overeducation in the Labour Market, a Meta-analysis'. Economics of Education Review, 19, 149-158.

Hartog, J. (1977), On the Multicapability Theory of Income Distribution, European Economic Review, 10, 157-171.

Hartog, J. (2000), Overeducation and Earnings: Where are we, Where should we go? Economics of Education Review, 19, 131-147.

Hartog, J. and H. Oosterbeek (1988), Education, Allocation and Earnings in the Netherlands: Overschooling?, Economics of Education Review, 7, 2, 185-194. 
Hersch, J. (1991), Education Match and Job Match, Review of Economics and Statistics, 73, $1,140-144$.

McGuinness, S. (2006), Overeducation in the Labour Market, Journal of Economic Surveys, $20,387-418$.

Mincer, J. (1974), Schooling, Experience, and Earnings, New York: NBER Press.

OECD (2009), OECD Indicators on Employment Protection - update 2009, Paris: OECD Publishing.

OECD (2011), OECD Employment Outlook 2011, Paris: OECD Publishing.

OECD (2013a), PIAAC Data, Paris: OECD.

OECD (2013b), Technical Report of the OECD Survey of Adult Skills (PIAAC). Paris: OECD Publishing.

OECD (2013c), Skills Outlook: first results from the OECD Survey of Adult Skills (Volume 1), Paris: OECD Publishing.

Quintini, G. (2011), Over-Qualified or Under-Skilled: A Review of Existing Literature, OECD Social, Employment and Migration Working Papers, No. 121, OECD Publishing.

Sattinger, M. (1993), Assignment Models of the Distribution of Earnings, Journal of Economic Literature, 31, 2, 851-880.

Sattinger, M. (2012), Qualitative Mismatches, Foundations and Trends in Microeconomics, 8, nr. 1-2, 1-168.

Sicherman, N. (1991), Overeducation in the Labour Market, Journal of Labour Economics, 9, $2,101-122$.

Sloane, P. (2003), Much Ado About Nothing? What Does the Overeducation Literature Really Tell Us?, in: F. Büchel, A. de Grip and A. Mertens (eds), Over-education in Europe: Current issues in theory and policy, Cheltenham: Edward Elgar. 
Sloane, D.J., Battu, H.B. and P. Seaman. (1999), Overeducation, Undereducation and the Britisch Labour Market, Applied Economics, 31, 11, 1437-1453.

Spence, M. (1973), Job Market Signalling, Quarterly Journal of Economics, 87, 1, 355-374. 
Table 1. Descriptive statistics

Std.

\begin{tabular}{lrrrr} 
& Minimum & Maximum & Mean & Deviation \\
\hline Numeracy skills & 80,39 & 420,24 & 284,34 & 47,11 \\
Literacy skills & 78,86 & 415,64 & 281,20 & 42,92 \\
Monthly wage (US\$) & 512,90 & 213198,31 & 3490,01 & 3497,65 \\
Required education & 0 & 22 & 12,93 & 3,13 \\
Overeducation & 0 & 18 & 0,89 & 1,78 \\
Undereducation & 0 & 14 & 0,51 & 1,27 \\
Age & 16 & 65 & 40,64 & 11,72 \\
Work experience & 0 & 55 & 19,87 & 12,18 \\
Number of working hours per week & 36 & 80 & 43,89 & 7,53 \\
1st generation migrants & 0 & 1 & 0,08 & 0,27 \\
1.5 generation migrants & 0 & 1 & 0,01 & 0,09 \\
2nd generation migrants & 0 & 1 & 0,02 & 0,13 \\
2.5 generation migrants & 0 & 1 & 0,05 & 0,21 \\
Remigrants & 0 & 1 & 0,01 & 0,09 \\
LMPI & 0,85 & 3,11 & 2,11 & 0,56 \\
\hline
\end{tabular}

$N=26322$ Source: PIAAC. 
Figure 1. The relationship between self-reported underutilizing and overutilization of skills and objective overeducation and undereducation
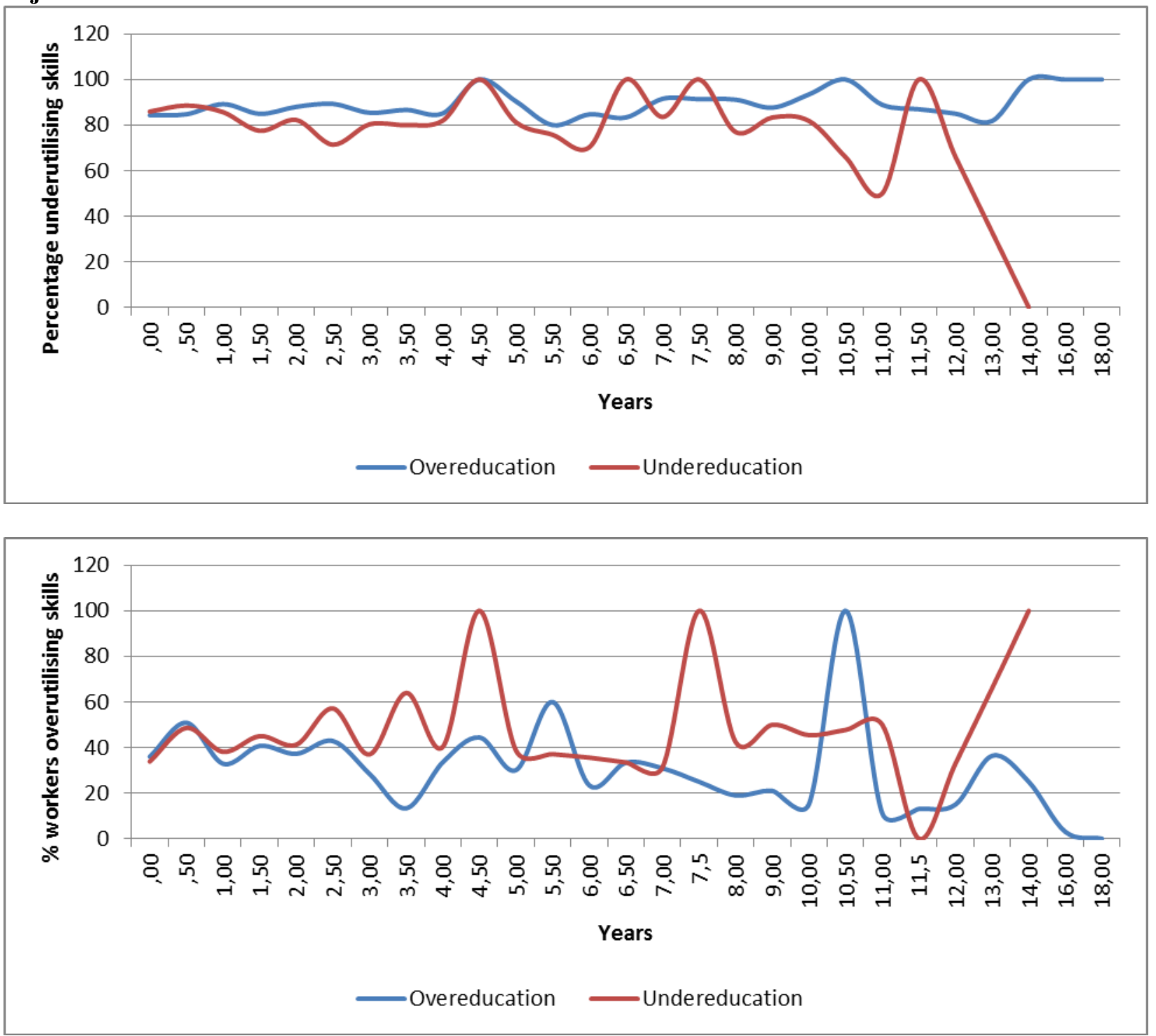
Table 2. ORU model: regression required education, overeducation and undereducation on logearnings

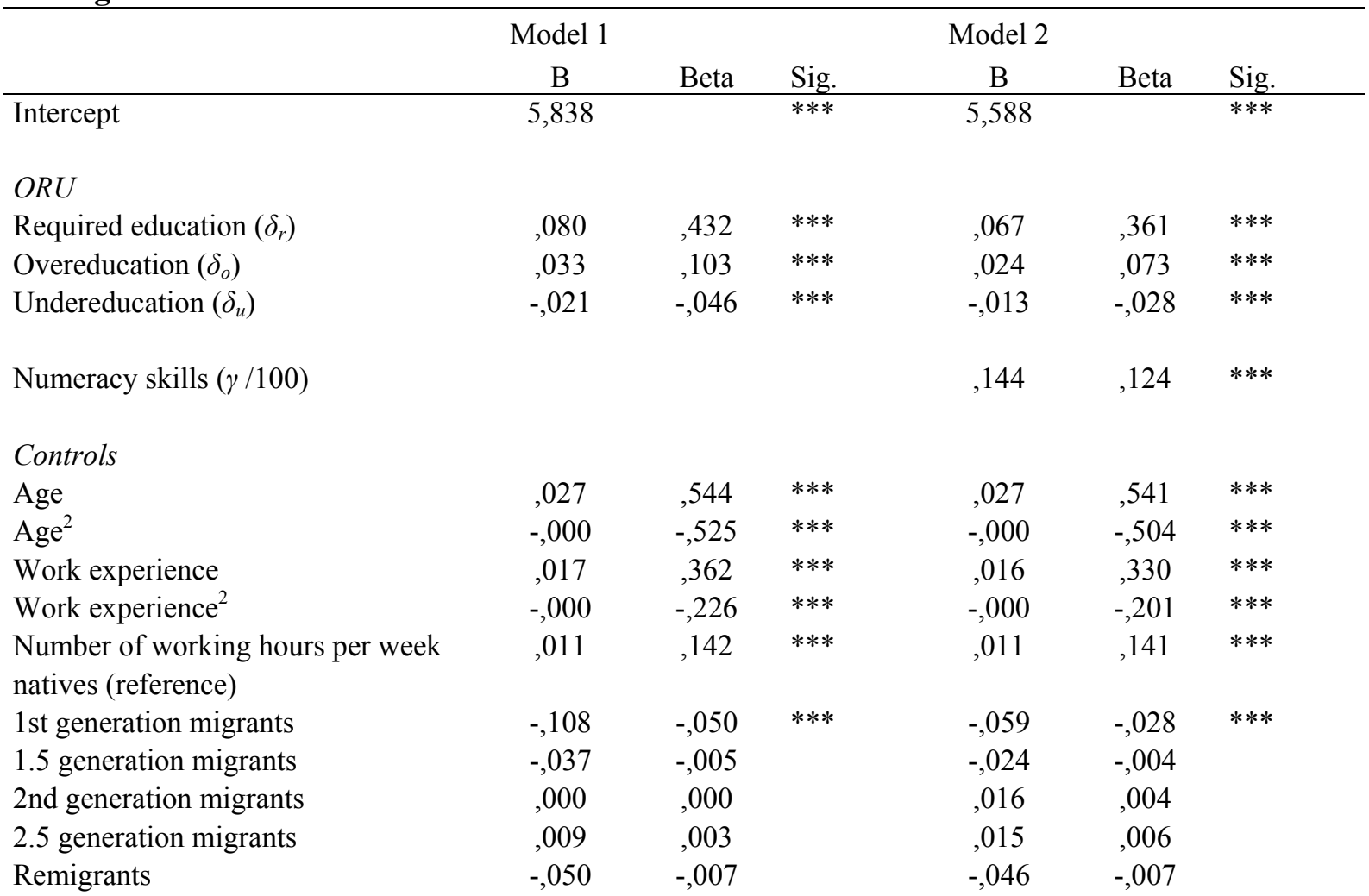

Country fixed effects

Austria (ref)

Belgium

Canada

Cyprus

Czech Republic

Denmark

Estonia

Finland

Germany

Ireland

Italy

Japan

Korea

Netherlands

Norway

Poland

Slovak Republic

Spain

Sweden

United Kingdom

United States

$\begin{array}{lclccc}, 069 & , 025 & * * * & , 065 & , 023 & * * * \\ , 119 & , 043 & * * * & , 142 & , 051 & * * * \\ -, 174 & -, 052 & * * * & -, 150 & -, 045 & * * * \\ -, 694 & -, 239 & * * * & -, 676 & -, 233 & * * * \\ , 271 & , 118 & * * * & , 269 & , 117 & * * * \\ -, 496 & -, 196 & * * * & -, 494 & -, 195 & * * * \\ , 053 & , 020 & * * * & , 044 & , 016 & * * \\ , 002 & , 001 & & , 017 & , 007 & \\ -, 014 & -, 004 & & , 036 & , 012 & * \\ -, 211 & -, 066 & * * * & -, 183 & -, 057 & * * * \\ -, 076 & -, 030 & * * * & -, 080 & -, 031 & * * * \\ -, 176 & -, 069 & * * * & -, 134 & -, 053 & * * * \\ , 029 & , 010 & & , 037 & , 013 & * \\ , 211 & , 083 & * * * & , 223 & , 087 & * * * \\ -, 713 & -, 311 & * * * & -, 676 & -, 295 & * * * \\ -, 767 & -, 268 & * * * & -, 751 & -, 262 & * * * \\ -, 221 & -, 074 & * * * & -, 193 & -, 064 & * * * \\ , 067 & , 024 & * * * & , 054 & , 020 & * * * \\ , 003 & , 001 & & , 017 & , 007 & \\ , 128 & , 040 & * * * & , 166 & , 051 & * * *\end{array}$

Adjusted $\mathrm{R}^{2}$ 0,594 0,604 
Table 3. ORU model by country: the returns to skills, the returns to required education, overeducation and undereducation on $\ln$ (earnings) and the proportion of effects explained by skills

\begin{tabular}{lcccc}
\hline & $\gamma$ & $\begin{array}{c}\% \delta_{r}{ }^{a} \\
\text { interpeted by } \gamma\end{array}$ & $\begin{array}{c}\% \delta_{o}{ }^{a} \\
\text { interpeted by } \gamma\end{array}$ & $\begin{array}{c}\% \delta_{u}{ }^{a} \\
\text { interpeted by } \gamma\end{array}$ \\
\hline Austria & 0,151 & 14 & 14 & 36 \\
Belgium & 0,104 & 17 & 18 & 30 \\
Canada & 0,151 & 21 & 27 & 29 \\
Cyprus & 0,053 & 4 & 11 & 11 \\
Czech Republic & 0,052 & 6 & 8 & 13 \\
Denmark & 0,084 & 11 & 23 & 93 \\
Estonia & 0,205 & 24 & 58 & $100^{s}$ \\
Finland & 0,071 & 9 & 16 & 9 \\
Germany & 0,221 & 22 & 40 & 91 \\
Ireland & 0,186 & 19 & 35 & 32 \\
Italy & 0,105 & 13 & 32 & 26 \\
Japan & 0,226 & 21 & 66 & 14 \\
Korea & 0,114 & 11 & 18 & 25 \\
Netherlands & 0,112 & 12 & 27 & 22 \\
Norway & 0,109 & 16 & 22 & 45 \\
Poland & 0,149 & 19 & 34 & 100 \\
Slovak Republic & 0,061 & 5 & 7 & 9 \\
Spain & 0,082 & 9 & 22 & 36 \\
Sweden & 0,095 & 15 & 33 & 42 \\
United Kingdom & 0,237 & 21 & 46 & 29 \\
United States & 0,211 & 23 & 60 &
\end{tabular}

Source: PIAAC ${ }^{* * *} p<.001 * * p<.01 * p<.05 .{ }^{\text {S Suppressor effect }}$ 
Figure 2. Country-level relationship between labor market institutions and the effect of numeracy skills of earnings

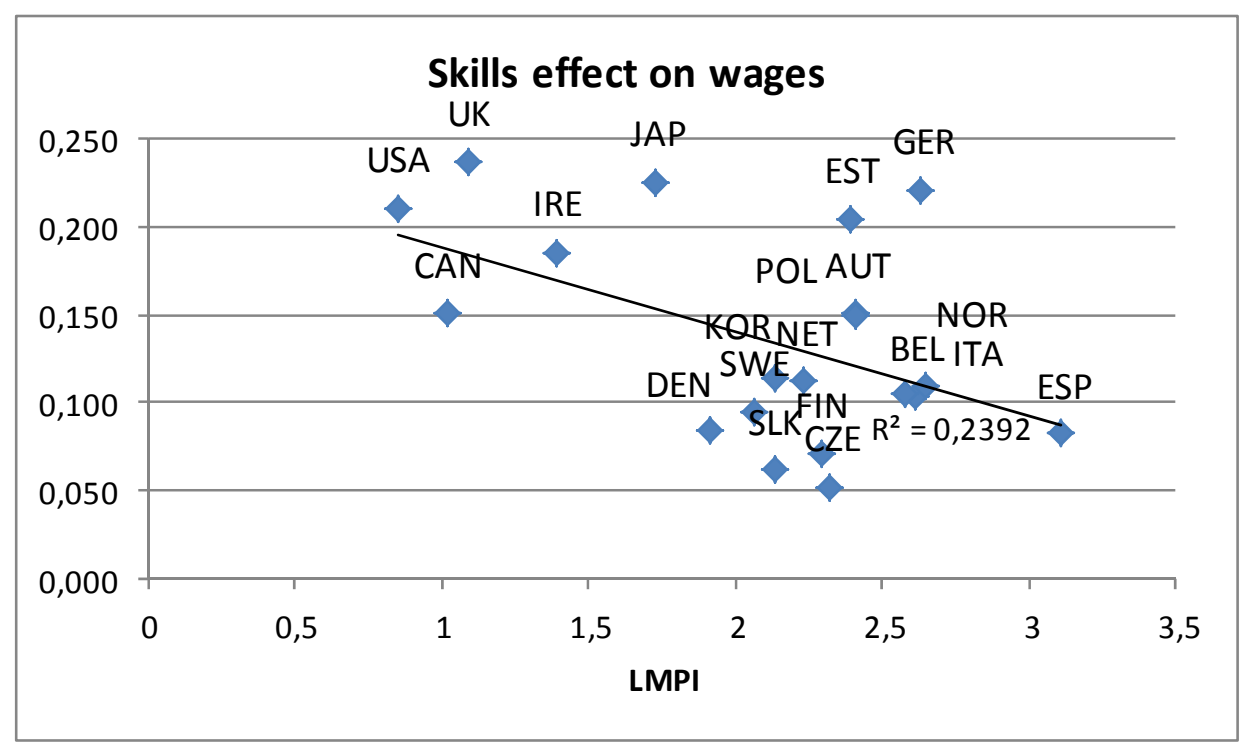

Source: PIAAC 
Figure 3: Relationship between labor market protection in countries and the extent to which effects of required education, overeducation and undereducation on log-earnings in these countries are explained by skills
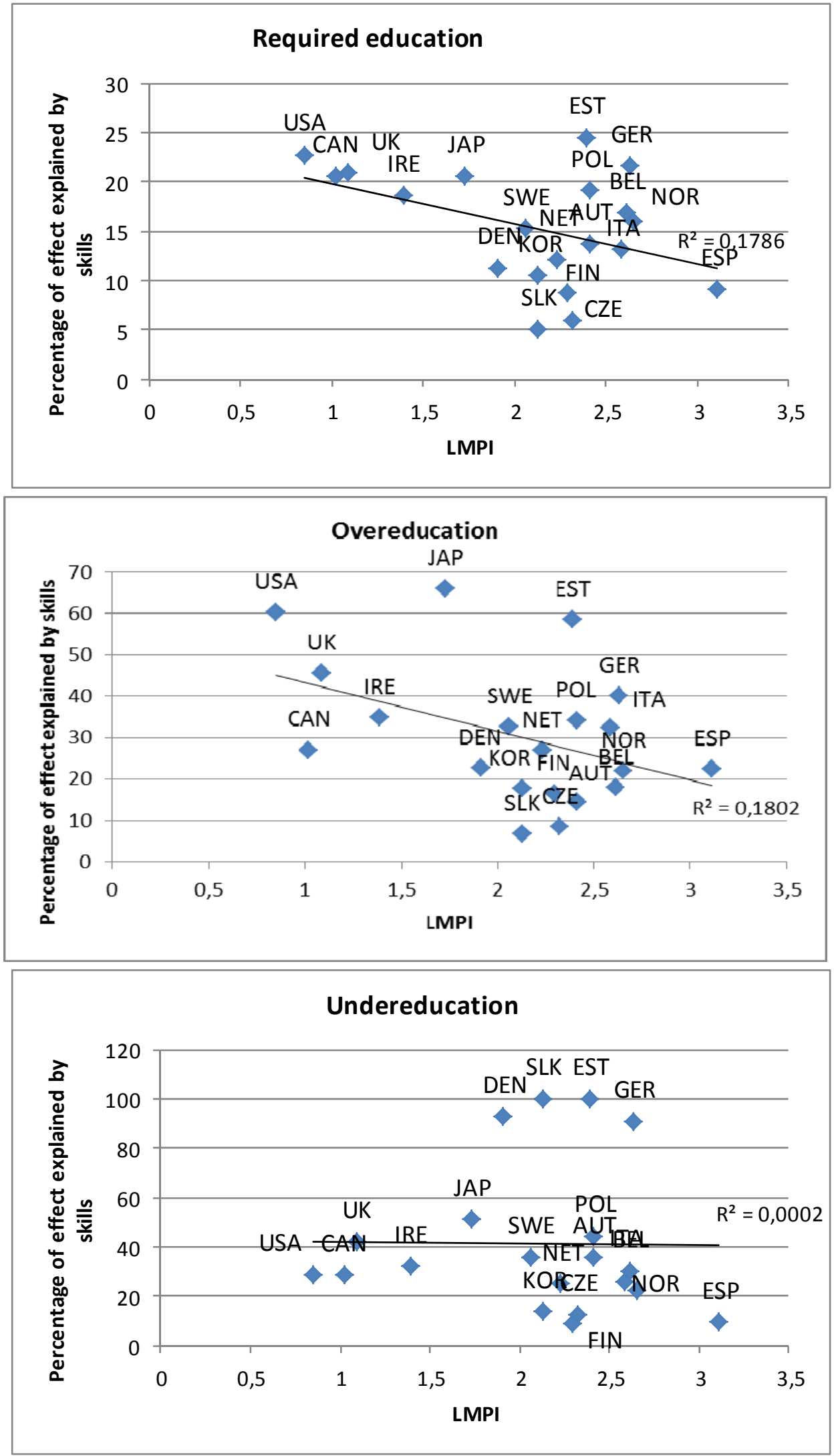

Source: PIAAC 
APPENDIX A1: Selections

$\bar{N}$

155156

excluding non-respondents

151692

selecting men

71988

selecting employed

43263

selecting fulltimers

35635

excluding students, interns, military personnel

32819

reweighting Canada

27974

listwise deleting missings

26322 


\begin{tabular}{|c|c|c|c|c|c|}
\hline & & Model 1 & & Model 2 & \\
\hline & & $b$ & $p$ & $b$ & $p$ \\
\hline \multirow[t]{15}{*}{ Austria } & Intercept & 5,697 &, 000 & 5,455 &, 000 \\
\hline & Required education &, 084 &, 000 &, 072 &, 000 \\
\hline & Overeducation &, 047 &, 000 &, 040 &, 000 \\
\hline & Undereducation &,- 007 & ,398 &,- 005 &, 582 \\
\hline & Age &, 019 &, 049 &, 016 & 095 \\
\hline & $\operatorname{Age}^{\wedge} 2$ &, 000 & ,282 & $-9,085 \mathrm{E}-05$ & ,425 \\
\hline & Work experience &, 016 &, 004 &, 017 & ,003 \\
\hline & Work experience ${ }^{\wedge} 2$ &, 000 &, 003 &, 000 &, 005 \\
\hline & Number of working hours &, 014 &, 000 &, 014 &, 000 \\
\hline & 1st generation migrants &,- 140 &, 000 &,- 077 &, 006 \\
\hline & 1.5 generation migrants &,- 016 &, 884 &,- 007 & ,950 \\
\hline & 2nd generation migrants &,- 013 &, 827 &, 011 &, 843 \\
\hline & 2.5 generation migrants &, 003 & ,939 &, 015 & ,687 \\
\hline & Remigrants &, 153 & ,491 &, 164 &, 451 \\
\hline & Numeracy & & &, 151 & ,000 \\
\hline \multirow[t]{15}{*}{ Belgium } & Intercept & 6,464 & ,000 & 6,386 & ,000 \\
\hline & Required education &, 066 &, 000 &, 055 &, 000 \\
\hline & Overeducation &, 045 &, 000 &, 037 &, 000 \\
\hline & Undereducation &,- 013 &, 040 &,- 009 &, 151 \\
\hline & Age &,- 002 &, 824 &,- 007 & ,494 \\
\hline & $\operatorname{Age}^{\wedge} 2$ &, 000 & ,202 &, 000 & ,086 \\
\hline & Work experience & 019 &, 001 &, 020 &, 000 \\
\hline & Work experience ${ }^{\wedge} 2$ &, 000 &, 000 &, 000 &, 000 \\
\hline & Number of working hours &, 012 &, 000 &, 012 &, 000 \\
\hline & 1st generation migrants &,- 012 &, 744 &, 031 & ,394 \\
\hline & 1.5 generation migrants &, 024 &, 846 &, 042 & ,726 \\
\hline & 2nd generation migrants &, 044 &, 522 &, 065 & ,337 \\
\hline & 2.5 generation migrants & ,006 &, 870 &, 007 &, 854 \\
\hline & Remigrants &, 007 & ,935 & ,009 & ,909 \\
\hline & Numeracy & & & ,104 &, 000 \\
\hline \multirow[t]{15}{*}{ Canada } & Intercept & 5,535 &, 000 & 5,317 & ,000 \\
\hline & Required education &, 085 &, 000 &, 067 &, 000 \\
\hline & Overeducation &, 053 &, 000 & 039 &, 000 \\
\hline & Undereducation &,- 028 &, 002 &,- 020 &, 025 \\
\hline & Age &, 030 &, 003 &, 032 & ,002 \\
\hline & $\operatorname{Age}^{\wedge} 2$ &, 000 &, 004 &, 000 &, 005 \\
\hline & Work experience &, 021 &, 000 & ,018 &, 001 \\
\hline & Work experience ${ }^{\wedge} 2$ &, 000 &, 011 &, 000 &, 023 \\
\hline & Number of working hours & ,016 &, 000 & ,016 &, 000 \\
\hline & 1st generation migrants &,- 168 &, 000 &,- 125 &, 000 \\
\hline & 1.5 generation migrants &, 090 & ,606 &, 060 & ,726 \\
\hline & 2nd generation migrants &,- 003 & ,963 &, 003 & ,958 \\
\hline & 2.5 generation migrants &, 023 & ,632 &, 025 &, 589 \\
\hline & Remigrants &,- 191 &, 144 &,- 181 &, 159 \\
\hline & Numeracy & & &, 151 &, 000 \\
\hline
\end{tabular}




\begin{tabular}{|c|c|c|c|c|c|}
\hline & & Model 1 & & Model 2 & \\
\hline & & $b$ & $p$ & $b$ & $p$ \\
\hline \multirow[t]{15}{*}{ Cyprus } & Intercept & 5,682 &, 000 & 5,572 &, 000 \\
\hline & Required education & 071 &, 000 & 068 &, 000 \\
\hline & Overeducation &, 017 &, 060 & 015 & ,096 \\
\hline & Undereducation &,- 033 &, 000 &,- 030 & 001 \\
\hline & Age &, 033 & 019 &, 033 &, 018 \\
\hline & $\operatorname{Age}^{\wedge} 2$ &, 000 &, 082 &, 000 & 074 \\
\hline & Work experience & 023 &, 001 &, 022 & 001 \\
\hline & Work experience ${ }^{\wedge} 2$ &, 000 &, 004 &, 000 &, 006 \\
\hline & Number of working hours &, 005 &, 001 &, 005 &, 001 \\
\hline & 1st generation migrants &,- 074 & 109 &,- 067 &, 151 \\
\hline & 1.5 generation migrants &,- 060 & 460 &,- 062 & ,446 \\
\hline & 2nd generation migrants &, 070 & ,712 &, 047 & ,806 \\
\hline & 2.5 generation migrants &,- 066 & ,476 &,- 065 & ,481 \\
\hline & Remigrants &, 111 &, 117 & , 107 &, 129 \\
\hline & Numeracy & & & 053 & 075 \\
\hline \multirow[t]{15}{*}{ Czech Republic } & Intercept & 6,130 &, 000 & 6,075 &, 000 \\
\hline & Required education & 078 &, 000 & 073 &, 000 \\
\hline & Overeducation &, 038 &, 000 & 035 &, 000 \\
\hline & Undereducation &,- 019 & 105 &,- 016 &, 159 \\
\hline & Age &,- 005 & ,698 &,- 007 & ,577 \\
\hline & $\operatorname{Age}^{\wedge} 2$ & $-9,642 \mathrm{E}-05$ &, 531 & $-6,862 \mathrm{E}-05$ & 657 \\
\hline & Work experience & 031 &, 000 & 032 &, 000 \\
\hline & Work experience ${ }^{\wedge} 2$ &, 000 &, 005 &, 000 &, 004 \\
\hline & Number of working hours &, 005 &, 000 &, 005 &, 000 \\
\hline & 1st generation migrants &, 048 & ,471 &, 060 & ,363 \\
\hline & 1.5 generation migrants &,- 069 & ,636 &,- 079 & ,591 \\
\hline & 2nd generation migrants & ,049 & ,608 &, 048 & ,615 \\
\hline & 2.5 generation migrants &,- 025 &, 540 &,- 023 & ,578 \\
\hline & Remigrants &,- 159 & ,400 &,- 166 & ,380 \\
\hline & Numeracy & & &, 052 &, 051 \\
\hline \multirow[t]{15}{*}{ Denmark } & Intercept & 6,043 & 0,000 & 5,916 & 0,000 \\
\hline & Required education & 068 &, 000 &, 060 &, 000 \\
\hline & Overeducation &, 025 &, 000 & ,019 &, 000 \\
\hline & Undereducation &,- 004 &, 500 & 000 & ,961 \\
\hline & Age & 032 &, 000 & 032 &, 000 \\
\hline & $\operatorname{Age}^{\wedge} 2$ &, 000 &, 000 &, 000 & 000 \\
\hline & Work experience & ,008 &, 015 & 007 &, 035 \\
\hline & Work experience ${ }^{\wedge} 2$ & $-9,461 \mathrm{E}-05$ & ,095 & $-7,739 \mathrm{E}-05$ & , 169 \\
\hline & Number of working hours &, 015 &, 000 &, 015 &, 000 \\
\hline & 1st generation migrants &,- 107 &, 000 &,- 070 &, 000 \\
\hline & 1.5 generation migrants &,- 020 &, 715 &,- 005 & ,933 \\
\hline & 2nd generation migrants & 033 & ,695 & ,062 & ,457 \\
\hline & 2.5 generation migrants & 036 &, 335 & 037 & ,312 \\
\hline & Remigrants &,- 160 &, 058 &,- 155 & 063 \\
\hline & Numeracy & & & ,084 & ,000 \\
\hline
\end{tabular}




\section{APPENDIX A2: Country-level analyses (continued)}

\begin{tabular}{|c|c|c|c|c|c|}
\hline & & Model 1 & & Model 2 & \\
\hline & & $\bar{b}$ & $p$ & $\bar{b}$ & $p$ \\
\hline \multirow[t]{15}{*}{ Estonia } & Intercept & 4,891 &, 000 & 4,569 &, 000 \\
\hline & Required education & ,072 &, 000 & 055 &, 000 \\
\hline & Overeducation & ,018 &, 050 & ,007 & ,417 \\
\hline & Undereducation &,- 005 & ,664 &, 002 & 882 \\
\hline & Age & ,055 &, 001 &, 051 &, 001 \\
\hline & $\operatorname{Age}^{\wedge} 2$ &,- 001 &, 000 &,- 001 &, 000 \\
\hline & Work experience & 013 & ,136 &, 013 & , 141 \\
\hline & Work experience ${ }^{\wedge} 2$ & $-9,887 \mathrm{E}-06$ & ,957 & $-2,002 \mathrm{E}-05$ & ,912 \\
\hline & Number of working hours & ,020 &, 000 &, 021 &, 000 \\
\hline & 1st generation migrants &,- 036 & ,462 &,- 012 & ,804 \\
\hline & 1.5 generation migrants &,- 129 & ,376 &,- 148 & 305 \\
\hline & 2nd generation migrants &,- 072 & ,119 &,- 047 & ,302 \\
\hline & 2.5 generation migrants &,- 085 &, 033 &,- 060 &, 130 \\
\hline & Remigrants &, 000 & ,999 &,- 026 & ,862 \\
\hline & Numeracy & & & ,205 & 000 \\
\hline \multirow[t]{15}{*}{ Finland } & Intercept & 6,086 & ,000 & 5,911 & ,000 \\
\hline & Required education &, 061 &, 000 &, 056 &, 000 \\
\hline & Overeducation & ,034 &, 000 &, 028 &, 000 \\
\hline & Undereducation &,- 014 &, 008 &,- 013 &, 015 \\
\hline & Age & ,013 & ,126 &, 014 & 095 \\
\hline & $\operatorname{Age}^{\wedge} 2$ & 000 &, 150 &, 000 & ,122 \\
\hline & Work experience & 023 &, 000 &, 022 &, 000 \\
\hline & Work experience ${ }^{\wedge} 2$ &, 000 &, 000 &, 000 &, 000 \\
\hline & Number of working hours &, 017 &, 000 & 017 &, 000 \\
\hline & 1st generation migrants &,- 179 &, 000 &,- 137 & ,003 \\
\hline & 1.5 generation migrants &, 518 &, 041 &, 558 & 027 \\
\hline & 2nd generation migrants &,- 371 &, 144 &,- 281 & ,267 \\
\hline & 2.5 generation migrants &,- 002 & ,971 &, 014 & 827 \\
\hline & Remigrants & 033 & ,684 &, 026 & ,747 \\
\hline & Numeracy & & &, 071 & 000 \\
\hline \multirow[t]{15}{*}{ Germany } & Intercept & 5,182 & ,000 & 4,858 & ,000 \\
\hline & Required education & ,117 &, 000 & ,092 &, 000 \\
\hline & Overeducation & 047 &, 000 &, 028 &, 001 \\
\hline & Undereducation &,- 018 &, 050 &,- 002 & ,856 \\
\hline & Age &, 040 &, 000 &, 040 & 000 \\
\hline & $\operatorname{Age}^{\wedge} 2$ &,- 001 &, 000 &, 000 &, 000 \\
\hline & Work experience & 011 &, 051 & ,009 & , 108 \\
\hline & Work experience ${ }^{\wedge} 2$ & $-7,668 \mathrm{E}-05$ & ,499 & $-3,457 \mathrm{E}-05$ & ,754 \\
\hline & Number of working hours &, 010 &, 000 &, 010 & 000 \\
\hline & 1st generation migrants & ,034 & ,304 &, 074 &, 020 \\
\hline & 1.5 generation migrants &,- 007 & ,941 &, 043 & ,661 \\
\hline & 2nd generation migrants & ,090 &, 032 & , 102 &, 012 \\
\hline & 2.5 generation migrants &,- 024 & ,433 &,- 027 & ,360 \\
\hline & Remigrants & ,294 &, 101 &, 231 & , 186 \\
\hline & Numeracy & & & ,221 & 000 \\
\hline
\end{tabular}




\section{APPENDIX A2: Country-level analyses (continued)}

\begin{tabular}{|c|c|c|c|c|c|}
\hline & & Model 1 & & Model 2 & \\
\hline & & $\bar{b}$ & $p$ & $\bar{b}$ & $p$ \\
\hline \multirow[t]{15}{*}{ Ireland } & Intercept & 5,267 &, 000 & 5,071 &, 000 \\
\hline & Required education & 085 &, 000 &, 069 &, 000 \\
\hline & Overeducation &, 026 &, 001 &, 017 &, 025 \\
\hline & Undereducation &,- 044 &, 000 &,- 030 & 001 \\
\hline & Age &, 038 & ,009 &, 034 &, 018 \\
\hline & $\operatorname{Age}^{\wedge} 2$ &, 000 &, 033 &, 000 &, 069 \\
\hline & Work experience &, 022 &, 001 &, 021 &, 001 \\
\hline & Work experience ${ }^{\wedge} 2$ &, 000 &, 068 &, 000 & 064 \\
\hline & Number of working hours & 013 &, 000 &, 013 &, 000 \\
\hline & 1st generation migrants &,- 125 &, 000 &,- 102 & 003 \\
\hline & 1.5 generation migrants &,- 061 & ,446 &,- 065 & 400 \\
\hline & 2nd generation migrants &, 081 & ,630 &, 068 & 680 \\
\hline & 2.5 generation migrants &,- 003 & ,968 &,- 017 & ,796 \\
\hline & Remigrants &,- 108 & ,143 &,- 123 & 087 \\
\hline & Numeracy & & & , 186 & 000 \\
\hline \multirow[t]{15}{*}{ Italy } & Intercept & 5,518 & ,000 & 5,314 & ,000 \\
\hline & Required education &, 062 &, 000 &, 054 &, 000 \\
\hline & Overeducation & ,019 & ,007 & 013 &, 070 \\
\hline & Undereducation &,- 024 &, 000 &,- 018 & 004 \\
\hline & Age &, 035 &, 002 &, 035 & 001 \\
\hline & $\operatorname{Age}^{\wedge} 2$ &, 000 &, 001 &, 000 & ,002 \\
\hline & Work experience &, 020 &, 000 &, 017 & 001 \\
\hline & Work experience ${ }^{\wedge} 2$ &, 000 & ,244 &, 000 & ,407 \\
\hline & Number of working hours &, 014 &, 000 &, 014 &, 000 \\
\hline & 1st generation migrants & ,002 & ,967 & ,028 &, 558 \\
\hline & 1.5 generation migrants &,- 128 & ,267 &,- 134 & ,241 \\
\hline & 2nd generation migrants &, 178 & ,442 & ,231 & ,313 \\
\hline & 2.5 generation migrants &, 056 & ,441 &, 066 & ,362 \\
\hline & Remigrants & ,008 & ,928 &, 014 & ,879 \\
\hline & Numeracy & & & 105 & 000 \\
\hline \multirow[t]{15}{*}{ Japan } & Intercept & 5,901 & ,000 & 5,511 & ,000 \\
\hline & Required education & ,090 &, 000 &, 071 &, 000 \\
\hline & Overeducation &, 021 &, 001 &, 007 & ,242 \\
\hline & Undereducation &,- 032 &, 002 &,- 016 & ,122 \\
\hline & Age & 015 & ,220 &, 013 & ,279 \\
\hline & $\operatorname{Age}^{\wedge} 2$ &, 000 & ,395 & $-9,408 \mathrm{E}-05$ & ,479 \\
\hline & Work experience &, 048 &, 000 &, 045 &, 000 \\
\hline & Work experience ${ }^{\wedge} 2$ &,- 001 &, 000 &,- 001 &, 000 \\
\hline & Number of working hours & 003 &, 005 &, 003 &, 001 \\
\hline & 1st generation migrants & & & & \\
\hline & 1.5 generation migrants & ,266 & ,208 & ,262 & ,201 \\
\hline & 2nd generation migrants & & & & \\
\hline & 2.5 generation migrants &, 080 &, 356 &, 101 & ,227 \\
\hline & Remigrants &,- 088 &, 808 &,- 121 & ,731 \\
\hline & Numeracy & & & ,226 &, 000 \\
\hline
\end{tabular}




\section{APPENDIX A2: Country-level analyses (continued)}

\begin{tabular}{|c|c|c|c|c|c|}
\hline & & Model 1 & & Model 2 & \\
\hline & & $\bar{b}$ & $p$ & $\bar{b}$ & $p$ \\
\hline \multirow[t]{15}{*}{ Korea } & Intercept & 5,193 &, 000 & 5,025 &, 000 \\
\hline & Required education & 087 &, 000 &, 078 &, 000 \\
\hline & Overeducation &, 032 &, 000 &, 026 &, 000 \\
\hline & Undereducation &,- 051 &, 000 &,- 043 &, 000 \\
\hline & Age &, 069 &, 000 &, 067 &, 000 \\
\hline & $\operatorname{Age}^{\wedge} 2$ &,- 001 &, 000 &,- 001 &, 000 \\
\hline & Work experience &, 025 &, 000 &, 025 &, 000 \\
\hline & Work experience ${ }^{\wedge} 2$ &, 000 & 055 &, 000 & 035 \\
\hline & Number of working hours &, 000 & ,649 &, 000 & ,724 \\
\hline & 1st generation migrants &,- 193 &, 025 &,- 118 & , 178 \\
\hline & 1.5 generation migrants & & & & \\
\hline & 2nd generation migrants & & & & \\
\hline & 2.5 generation migrants &, 026 &, 812 &, 024 & 828 \\
\hline & Remigrants &, 064 & ,640 & ,092 & ,501 \\
\hline & Numeracy & & &, 114 & 000 \\
\hline \multirow[t]{15}{*}{ Netherlands } & Intercept & 4,838 & ,000 & 4,725 & ,000 \\
\hline & Required education & ,097 &, 000 & 085 &, 000 \\
\hline & Overeducation &, 034 &, 000 &, 025 & ,002 \\
\hline & Undereducation &,- 023 &, 000 &,- 017 & 003 \\
\hline & Age &, 062 &, 000 &, 059 &, 000 \\
\hline & $\operatorname{Age}^{\wedge} 2$ &,- 001 &, 000 &,- 001 &, 000 \\
\hline & Work experience &,- 003 &, 509 &,- 003 &, 524 \\
\hline & Work experience ${ }^{\wedge} 2$ & $5,131 \mathrm{E}-05$ & ,619 & $5,664 \mathrm{E}-05$ & ,579 \\
\hline & Number of working hours &, 013 &, 000 &, 013 &, 000 \\
\hline & 1st generation migrants &,- 159 &, 000 &,- 112 & ,002 \\
\hline & 1.5 generation migrants &,- 040 & ,624 &,- 020 & 807 \\
\hline & 2nd generation migrants &,- 029 & ,761 &,- 009 & ,925 \\
\hline & 2.5 generation migrants &, 104 &, 009 & , 107 & ,006 \\
\hline & Remigrants & ,136 & ,284 &, 170 & , 176 \\
\hline & Numeracy & & &, 112 & 000 \\
\hline \multirow[t]{15}{*}{ Norway } & Intercept & 6,159 & ,000 & 6,018 & ,000 \\
\hline & Required education &, 067 &, 000 &, 056 &, 000 \\
\hline & Overeducation &, 040 &, 000 & ,031 &, 000 \\
\hline & Undereducation &,- 027 &, 000 &,- 021 &, 001 \\
\hline & Age &, 025 &, 000 & ,023 & 001 \\
\hline & $\operatorname{Age}^{\wedge} 2$ &, 000 &, 001 &, 000 & ,002 \\
\hline & Work experience &, 012 & ,003 &, 010 & ,008 \\
\hline & Work experience ${ }^{\wedge} 2$ &, 000 &, 021 &, 000 &, 044 \\
\hline & Number of working hours & 015 &, 000 &, 015 & 000 \\
\hline & 1st generation migrants &,- 156 &, 000 &,- 095 &, 000 \\
\hline & 1.5 generation migrants &,- 039 & ,609 &,- 026 & ,734 \\
\hline & 2nd generation migrants &,- 068 & ,421 &,- 033 & 695 \\
\hline & 2.5 generation migrants &, 035 & ,306 &, 041 & ,229 \\
\hline & Remigrants &,- 092 &, 181 &,- 089 & , 191 \\
\hline & Numeracy & & & 109 &, 000 \\
\hline
\end{tabular}




\begin{tabular}{|c|c|c|c|c|c|}
\hline & & $\overline{\text { Model } 1}$ & & Model 2 & \\
\hline & & $\bar{b}$ & $p$ & $\bar{b}$ & $p$ \\
\hline \multirow[t]{15}{*}{ Poland } & Intercept & 5,526 &, 000 & 5,235 &, 000 \\
\hline & Required education & 073 &, 000 & 059 &, 000 \\
\hline & Overeducation & 033 &, 000 &, 022 &, 001 \\
\hline & Undereducation &,- 027 &, 002 &,- 015 & ,086 \\
\hline & Age & ,012 & ,248 &, 015 & ,122 \\
\hline & $\operatorname{Age}^{\wedge} 2$ & 000 &, 070 &, 000 & 037 \\
\hline & Work experience & ,026 &, 000 &, 024 &, 000 \\
\hline & Work experience ${ }^{\wedge} 2$ &, 000 &, 004 &, 000 &, 005 \\
\hline & Number of working hours & 011 &, 000 &, 011 &, 000 \\
\hline & 1st generation migrants & & & & \\
\hline & 1.5 generation migrants & ,206 &, 451 &, 233 & ,387 \\
\hline & 2nd generation migrants & 181 &, 164 &, 173 &, 178 \\
\hline & 2.5 generation migrants & ,056 & ,379 &, 042 & ,499 \\
\hline & Remigrants & 140 & ,608 & , 162 &, 549 \\
\hline & Numeracy & & &, 149 &, 000 \\
\hline \multirow[t]{15}{*}{ Slovak Republic } & Intercept & 5,408 &, 000 & 5,277 &, 000 \\
\hline & Required education & ,099 &, 000 & ,094 &, 000 \\
\hline & Overeducation & ,067 &, 000 &, 063 &, 000 \\
\hline & Undereducation & ,002 & ,932 & 003 & ,897 \\
\hline & Age & ,006 & ,769 & ,007 & ,727 \\
\hline & $\operatorname{Age}^{\wedge} 2$ & 000 & ,394 &, 000 & ,388 \\
\hline & Work experience & 020 &, 071 & ,019 & ,092 \\
\hline & Work experience ${ }^{\wedge} 2$ &, 000 & ,283 &, 000 & ,309 \\
\hline & Number of working hours & 011 &, 000 &, 011 &, 000 \\
\hline & 1st generation migrants & ,076 & ,782 & ,086 & ,753 \\
\hline & 1.5 generation migrants & , 129 & ,480 &, 132 &, 470 \\
\hline & 2nd generation migrants &,- 069 & ,692 &,- 069 & 693 \\
\hline & 2.5 generation migrants & 079 & ,272 & 077 & ,286 \\
\hline & Remigrants &,- 047 & ,787 &,- 041 &, 811 \\
\hline & Numeracy & & &, 061 & ,146 \\
\hline \multirow[t]{15}{*}{ Spain } & Intercept & 5,995 &, 000 & 5,862 &, 000 \\
\hline & Required education & ,068 &, 000 &, 062 &, 000 \\
\hline & Overeducation & 021 &, 000 &, 016 &, 006 \\
\hline & Undereducation &,- 033 &, 000 &,- 030 &, 000 \\
\hline & Age & ,036 &, 001 &, 035 &, 001 \\
\hline & $\operatorname{Age}^{\wedge} 2$ &, 000 &, 001 &, 000 &, 002 \\
\hline & Work experience & 009 & 081 & 009 & 095 \\
\hline & Work experience ${ }^{\wedge} 2$ & $-5,522 \mathrm{E}-05$ & ,611 & $-4,013 \mathrm{E}-05$ & ,711 \\
\hline & Number of working hours & ,003 &, 040 &, 004 &, 025 \\
\hline & 1st generation migrants &,- 145 &, 000 &,- 119 &, 002 \\
\hline & 1.5 generation migrants &,- 068 &, 380 &,- 042 & ,589 \\
\hline & 2nd generation migrants &,- 286 &, 137 &,- 290 &, 130 \\
\hline & 2.5 generation migrants & ,006 & ,939 & 022 & ,796 \\
\hline & Remigrants & ,002 & ,985 &, 014 & ,897 \\
\hline & Numeracy & & & 082 & 001 \\
\hline
\end{tabular}




\begin{tabular}{|c|c|c|c|c|c|}
\hline & & Model 1 & & Model 2 & \\
\hline & & $b$ & $p$ & $b$ & $p$ \\
\hline \multirow[t]{15}{*}{ Sweden } & Intercept & 6,539 & ,000 & 6,349 & ,000 \\
\hline & Required education & ,067 &, 000 &, 057 &, 000 \\
\hline & Overeducation & ,027 & 000 &, 018 &, 012 \\
\hline & Undereducation &,- 013 &, 030 &,- 008 &, 164 \\
\hline & Age &,- 006 & ,443 &,- 005 &, 553 \\
\hline & $\operatorname{Age}^{\wedge} 2$ &, 000 & ,262 & $9,151 \mathrm{E}-05$ & ,326 \\
\hline & Work experience &, 020 &, 000 & 020 &, 000 \\
\hline & Work experience ${ }^{\wedge} 2$ &, 000 &, 000 &, 000 &, 000 \\
\hline & Number of working hours & ,014 &, 000 &, 014 &, 000 \\
\hline & 1st generation migrants &,- 059 & 011 &,- 011 & ,640 \\
\hline & 1.5 generation migrants &,- 041 &, 721 &,- 026 &, 819 \\
\hline & 2nd generation migrants & ,022 & 652 &, 033 & ,506 \\
\hline & 2.5 generation migrants & ,022 & ,457 & ,020 & ,492 \\
\hline & Remigrants &,- 084 &, 427 &,- 032 & ,763 \\
\hline & Numeracy & & & ,095 &, 000 \\
\hline \multirow[t]{15}{*}{ United Kingdom } & Intercept & 4,687 & ,000 & 4,276 &, 000 \\
\hline & Required education &, 118 &, 000 & ,094 &, 000 \\
\hline & Overeducation & ,034 &, 000 & ,018 &, 015 \\
\hline & Undereducation &,- 027 & ,006 &,- 015 & ,101 \\
\hline & Age &, 044 &, 001 & ,049 &, 000 \\
\hline & $\operatorname{Age}^{\wedge} 2$ &, 000 &, 004 &,- 001 &, 001 \\
\hline & Work experience & ,012 &, 084 & ,009 &, 190 \\
\hline & Work experience ${ }^{\wedge} 2$ &, 000 & ,140 &, 000 & ,376 \\
\hline & Number of working hours & ,018 &, 000 &, 017 &, 000 \\
\hline & 1st generation migrants &,- 083 &, 019 &,- 018 & ,610 \\
\hline & 1.5 generation migrants &,- 021 &, 850 &,- 031 &, 772 \\
\hline & 2nd generation migrants & ,021 &, 717 & ,076 &, 173 \\
\hline & 2.5 generation migrants & ,025 &, 542 &, 050 & ,200 \\
\hline & Remigrants &,- 078 &, 434 &,- 086 &, 367 \\
\hline & Numeracy & & & ,237 &, 000 \\
\hline \multirow[t]{15}{*}{ United States } & Intercept & 4,845 & ,000 & 4,701 & ,000 \\
\hline & Required education & ,117 &, 000 & ,090 &, 000 \\
\hline & Overeducation & ,036 &, 001 &, 014 & ,186 \\
\hline & Undereducation &,- 066 &, 000 &,- 047 &, 001 \\
\hline & Age &, 053 &, 000 &, 051 &, 000 \\
\hline & $\operatorname{Age}^{\wedge} 2$ &,- 001 &, 002 & ,000 &, 004 \\
\hline & Work experience & ,004 & ,609 & 003 & ,737 \\
\hline & Work experience ${ }^{\wedge} 2$ & $-6,820 \mathrm{E}-05$ & 651 & $-6,669 \mathrm{E}-05$ &, 651 \\
\hline & Number of working hours &, 013 &, 000 &, 012 &, 000 \\
\hline & 1st generation migrants &,- 068 &, 157 &,- 013 & ,790 \\
\hline & 1.5 generation migrants &, 151 & ,398 &, 153 & ,380 \\
\hline & 2nd generation migrants &,- 067 & ,417 &,- 052 &, 519 \\
\hline & 2.5 generation migrants &,- 013 &, 859 &,- 012 &, 867 \\
\hline & Remigrants &,- 101 &, 542 &,- 103 &, 523 \\
\hline & Numeracy & & & ,211 &, 000 \\
\hline
\end{tabular}

